\title{
Quality of the Financial Reporting within the IFRS: Research on Determining the Attitudes and Evaluations of Financial Information Users
}

Ali İhsan Akgün*

\section{ABSTRACT}

The transition to International Financial Reporting Standards (IFRS) in Turkey can lead to important effects on the financial reports of businesses, and the process of analyzing these reports. A change in the offices of financial reports required of businesses is due to the transition to IFRS. This study examines whether IFRS affects the process of financial reporting. The study measures the effects and perceptions of IFRS the process of financial reporting on businesses operating on the Istanbul Stock Exchange (ISE). This article adds to the literature by estimating the attitudes and evaluations of financial managers, analysis and investor with respect to the effect of IFRS harmonization on financial performance of listed firms in Turkey and providing analyses on the quality of financial reporting. A questionnaire survey was used, and data were analyzed via multi-regression analysis.

Anahtar Kelimeler: International Accounting and Financial Reporting Standards, Financial Analysis, Quality, Istanbul Stock Exchange.

JEL Sinıflandırması: M40, M41, M49.

IFRS Kapsamında Finansal Raporlamanın Kalitesi: Finansal Bilgi Kullanıcılarının Tutum ve Değerlendirmelerinin Belirlenmesine Yönelik Araştırma

\section{$\ddot{O Z Z E T}$}

Türkiye'de Uluslararası Finansal Raporlama Standartları (IFRS) uygulamalarına geçiş, işletmelerin finansal tablolarında ve bu tabloların finansal raporlama sürecinin analizinde önemli etkilere yol açabilir. IFRS'lere geçiş ile birlikte işletmelerin finansal tablo kalemlerinde değişim meydana getirmektedir. Bu çalışma, IFRS'nın finansal raporlama sürecine yönelik etkileme süreci olup olmadığının belirlenmesi amaçlanmıştır. Bu çalışmada, IFRS kapsamında finansal raporlama sürecinin İstanbul Menkul Klymetler Borsası'nda faaliyet gösteren işletmeler üzerindeki etkilerini ve algılamalarını ölçmek amaçlanmıştır. Bu çalışma, finansal raporlamanın kalitesine analiz sağlaması ve Türkiye'de borsaya kayltl firmalarda finansal performansin IFRS uyumuna etkisinin belirlenmesinde finans yöneticilerinin, analistlerin ve yatırımclları tutum ve değerlendirmelerinin benimsenmesi açısından literatüre katkı sağlanması beklenmektedir. Çalışmada anket yöntemi kullanılmış olup, ankete ilişkin sorular çoklu regresyon analizine tabi tutulmuştur.

Keywords: Uluslararası Finansal Raporlama Standartları, Finansal Analiz, Kalite, İstanbul Menkul Kiymetler Borsası.

Jel Classification: M40, M41, M49.

\footnotetext{
* Doç.Dr. Ali İhsan Akgün, Yıldırım Beyazıt University, Business School, akgun@ybusm.info aliihsan_akgun@hotmail.com.
} 


\section{INTRODUCTION}

The development of accounting practices in Turkey is heavily influenced by the practices of a number of Western countries as a result of the economic and political ties in a specific period. The first Commercial Code of 1850 was a translation of the French Commercial Code (Simga-Mugan and Hosal-Akman, 2005). A second Commercial Code was enacted by Law number 826, in 1926 based on the German commerce and company laws that controlled the accounting rules (Simga-Mugan and Hosal-Akman, 2012).

1950s on American expertise has been utilized and the Turkish economic systemheavily influenced by the American system. Istanbul Stock Exchange (ISE) came out in 1984; full operations started in 1986, and it is still the only stock exchange in Turkey. The foundation of the Capital Markets Board (CMB) and the ISE, and the increase in foreign investments. Until the establishment of the CMB and the ISE, legal requirements were the main influence on the financial accounting system. Consequently, the Procedural Tax Code heavily influenced accounting practice in Turkey (Simga-Mugan and Hosal-Akman, 2005).

The first set of financial accounting standards was developed in January 1989 by the CMB to be in effect for the fiscal years that started on or after 1 January 1989 Serial X, No. 11 (www.spk.gov.tr). A revised version of these standards is still effect, and regulates the preparation and presentation of financial statements of publicly owned companies. The standards are comparable with the IFRS (Simga-Mugan and Hosal-Akman, 2012).

In 1992, the Ministry of Finance organized a committee to establish accounting principles and a uniform chart of accounts that would be used by all companies. The ministry published the committee's report in a communiqué on 26 December 1992 establishing the principles and the Turkish Uniform Chart of Accounts (TUCA) to take effect 1 January 1994. All companies except banks, brokerage firms and insurance companies are required to conform to the guidelines stated in the communiqué. In November 2003, the CMB issued a communiqué to adapt the financial reporting standards of traded companies in ISE to IAS and IFRS (Series XI, No. 25). The standards were mandatory for all publicly traded companies and intermediary institutions from the beginning of 2005.

The new standards in the communiqué are essentially the same as IAS/IFRS except for the amendments by the IASB after 2004 (Simga-Mugan and Hosal-Akman, 2005). In 2002, Turkish Accounting Standards Board (TASB), held its first meeting and the Board translated the IFRS, and also has issued the framework in addition to twelve IFRS and thirty-one IAS by the end of 2011. The Board also published application guidelines for these accounting standards. As a result of the reorganization on 2 November 2011 the TASB is dissolved and Public Oversight, Accounting and Auditing Standards Authority is formed under the prime ministry. The authority has the responsibility to issue accounting and auditing standards, as well as licencing the auditors and overseeing the system and conducting the activities of TASB (Simga-Mugan and Hosal-Akman, 2012). This study focuses on quality of the financial 
reporting within the IFRS by determining the attitudes and evaluations of financial information users.

The mandatory adoption of IFRS has been motivated by the need to ensure greater comparability and a higher transparency and quality of financial reporting around the world. IFRS is necessary in achieving higher quality reports in order to get market gain. Higher quality financial reporting can improve stock market liquidity and reduces the cost of capital. Some empirical evidence on the market outcomes of mandatory IFRS adoption generally supports these predictions (Hail, 2011; Li, 2010; Daske et al. 2008; Barth et al., 2008; Hung and Subramanyam, 2007; Daske, 2006; Cuijpers and Buijink, 2005). This study examines the importance of the international dimension in financial reporting; and the attitudes and evaluations of financial managers with respect to the effect of IFRS convergence on financial performance.

Prior research argued that firms using IFRS generally exhibit higher accounting quality than firms using local GAAP (Barth et al., 2008). Prior research also documents numerous capital market benefits of IFRS adoption, including reduced cost of capital and improved liquidity (Daske et al., 2008; Li, 2010), higher foreign investment (Covrig et al., 2007; DeFond et al., 2011), and impact on the quality of accounting numbers (Daske, 2006; Stecher and Suijs, 2012). Similarly, these studies suggest that firms applying IFRS should have higher financial reporting quality and greater comparability than those applying domestic accounting standards (Landsman et al., 2012; Cuijpers and Buijink, 2005; Christensen et al., 2007; Barth et al., 2008).

While many studies document that the adoption of IFRS is associated with economic consequences such as earnings quality, stock liquidity, and investor ownership (e.g., Young and Guenther, 2002; Bushman and Piotroski, 2006; Covrig et al., 2007), it is an important and resolved issue whether the effect of IFRS comes from an increase in accounting quality and in financial reporting comparability (Hamberg et al., 2013; Hail et al., 2010). In the present research, I investigate the determining financial analysis quality and the effect of financial reporting within the IFRS among businesses operating on the ISE.

This paper contributes to the literature by identifying a setting in which financial reporting quality remains constant. The study examines the conceptual basis for the importance of the international dimension in financial reporting. A questionnaire study was used to evaluate the effects of quality on financial reporting within the IFRS among businesses operating on the ISE. Therefore, a questionnaire survey was used, and data were analyzed via regression analysis.

The remainder of this paper is structured as follows. The next section offers an overview of the literature review and hypotheses. Section 3 presents the research design, purpose of the research and data source. Section 4 describes the empirical evidence. A discussion and conclusion remarks follows. 


\section{REVIEW OF RELEVANT LITERATURE}

\subsection{Background}

There is a significant body of theoretical and empirical literature in accounting and finance that considers the relationship between analysis of financial reporting process and IFRS. Some studies suggest that IFRS is of high quality financial reporting. For instance, Van Tendeloo and Vanstraelen (2005) discussed whether there was a relationship between harmonization to high quality standards such as the IFRS, and high quality of financial reporting. Goodwin et al. (2008) provided evidence of the effects of IFRS on the accounts and accounting quality of a sample of Australian listed firms.

Stoian et al. (2009) emphasized that the purpose of financial statement analysis with IFRS was the necessity of presenting more qualified information to users of financial information when considering economic decisions. Richardson and Tuna (2009) defined the quality of financial reporting such that financial reports were associated with the performance of current business activity, and the prediction accuracy of future cash flow. Choi and Pae (2011) find that corporate commitment to business ethics has perpetuating effects on future financial reporting quality. Gebhardt and Novotny-Farka (2011) examined the implications of mandatory IFRS adoption on the accounting quality of banks in twelve EU countries. Outa (2011) emphasized that the status of the impact of IFRS adoption leads to better results on the quality of accounting in Kenya.

Landsman et al. (2012) found that both before and after IFRS firms adopt IFRS accounting quality is higher for US firms, and that all three dimensions of accounting quality are potential sources of the increase in comparability after IFRS firms adopt IFRS. Jiao et al. (2012) examined that the adoption of IFRS has improved the quality of financial reports and, more specifically the quality of earnings. Similarly, Landsman et al. (2012) examined the quality of accounting information in terms of adoption of IFRS.

Horton et al. (2013) investigate whether IFRS adoption is likely to generate both information and comparability effects and improve the quality of information intermediation in capital markets. The main motivation of the present study is to re-examine the findings reported by Akgün (2013), by using the same data set to conduct regression analysis and thereby revealing positive or negative effects of the variables on the reliability of financial information and quality of financial analysis within the research on IFRS. Present paper differs from the prior literature in two important ways. First, the study main results for higher quality financial reporting under the IFRS generally hold after controlling for various analyst. These study analysts following results are robust to a wide variety of modifications in our research design, and are corroborated by regression analysis and ANOVA analysis on a sample of ISE firms voluntarily adopting IFRS. Second, in the study, results were reached concerning the capacity of IFRS's to provide more reliable financial information in the taking of important decisions in the ISE businesses, to increase the level of quality financial 
reporting analysis and to present higher quality information to the financial statements user.

Macías and Muiño (2011) suggested a quality problem in the accounting information of some European countries that operate two different national and international accounting systems. Atwood et al. (2011) found that accounting information presented according to generally accepted accounting principles was more successful in the predictability dimension than information presented according to the IFRS system.

Prior research, for example, Petreski (2006) examined the effect of IFRS on the analysis of financial reports of businesses and found that important changes occurred both in balance sheet and income statements of businesses using IFRS. Ding and $\mathrm{Su}$ (2008) emphasized in their studies comparing two different accounting systems, namely changes which result from different implementations of realistic value applications. Lantto and Sahlström (2009) concluded that the changes in the financial leverage ratio caused increased borrowing but decreased equity. Consequently, financial ratios were revealed to change in the transition from local account standards to IFRS. Blanchette et al. (2011) examined the effect of IFRS on financial ratios in the field of liquidity, financial leverage and profitability among Canadian companies. Compared with generally accepted accounting standards for Canada, IFRS harmonization had the effect of promoting realistic values in accounting and facilitating clearer comparative income statements.

Jones and Higgins (2006) concluded that IFRS harmonization caused an important development in the organizational functions and responsibilities in the departments of businesses. Callao et al. (2007) examined the quantitative effect of IFRS harmonization in financial offices and ratios and the difference between the market value and book value of the business was analyzed to determine the effects of IFRS harmonization.

Cortesi et al. (2009) examined IAS/IFRS harmonization to the financial statements of furniture and decoration sector companies registered on the Milano Stock Exchange in 2005. The application of international accounting standards resulted in basic differences and effects in tangible and intangible assets according to IAS 38 and IAS 36.

Iatridis (2010a) dealt with the effect of the harmonization to IFRS in measuring the financial performance of businesses. The study stated that the existence of loan power and credibility of business could decrease potential business risk and increase financial reporting quality with IFRS. In another study Iatridis (2010b) researched whether IFRS harmonization increased the quality of accounting information. Trust in the IFRS-based financial statements information was increased and the quality of accounting increased. Navarro-García and Bastida (2010) analyzed the consequences of IFRS adoption in a code-law country in Spain. This study indicates that statement preparers' overall views of IFRS could lead to less IFRS compliance and, therefore, lower quality financial reports than could be reached under strict IFRS application. 


\subsection{Hypothesis Development}

In this section, two hypotheses with regard to the effects of introducing IFRS financial reporting processes in the ISE will be discussed. The first deals with the forecast accuracy of financial analysts based on the different financial accounting regimes. Ernstberger et al. (2008) analyzed the increase in the quantity and quality of disclosures on financial reporting accuracy after the adoption of IFRS or US GAAP. However, the effect of applying different accounting regimes on the forecast accuracy of financial analyses is not obvious. After the adoption of IFRS or US GAAP, the analysts should receive more information about the company's financial position, enabling them to build their prediction based on larger information set.

The first objective of the study is, therefore, to examine the impact of mandatory IFRS adoption on financial analysts' forecast accuracy in Turkey. In this study, it will be analyzed whether mandatory adoption of IFRS has positive effects on the accuracy of financial analysis of listed firms. Therefore, the first hypothesis will be stated as follows:

$\mathbf{H 1}=$ IFRS affects the level of reaching more accurate information from financial reporting.

The second issue is that, if IFRS reduces the value-relevance of accounting information by limiting the financial analysts' information set in relation to the listed firms, then IFRS adoption will affect positively the quality of the financial analysis of businesses. Barth et al. (2008) compare accounting quality metrics for firms that apply IAS to those for a matched sample of non-U.S. firms that do not in the period after the IAS firms adopt IAS. They find that IAS firms have higher accounting quality than firms that do not apply IAS. Also, differences in accounting quality between the two groups of firms in the period before the IAS firms adopt IAS do not account for the post-adoption differences.

Barth et al. (2008) affirm that IFRS reporting improves the quality of a firm's financial reporting. We find that IAS firms have higher accounting quality than firms that do not apply IAS. Iatridis (2010b) emphasized that the higher disclosure requirements and financial reporting quality that stem from IFRS implies that the adoption of IFRS give a positive signal to investors as information asymmetry. Thus, firms reporting under IFRS would be expected to exhibit higher quality accounting measures. Subsequently, the study would predict that the particular accounting measures display higher value relevance. Higher accounting quality in the official adoption period would be associated with the change in the financial reporting system. Aljifri (2012) implies that the enhancement of the quality of financial reporting of IFRS is based on the notion that using a common accounting standard is expected to improve the quality of financial reporting. IFRS encourages managers to be creative and to use professional judgment, which will decrease the comparability, transparency, relevance and reliability of financial information, and hence have an impact on the quality of reporting. According to Armstrong et al. (2010) investors expected the application of IFRS to result in 
higher quality financial reporting information, thereby lowering information asymmetry among the firm, investors and information risk.

Thus, the hypothesis examining whether accuracy of financial analysis has increased and affected the quality of the financial analysis of businesses complying to IFRS on companies operating in the ISE takes the following form:

$\mathbf{H}_{2}=$ IFRS present more accurate information to the users of financial information, by positively affecting the quality of the financial reporting of businesses.

In order to examine the two hypotheses, questionnaire responses were analyzed. The analysis tested the effects of the dependent variables supporting the hypothesis, and of independent variables having effect on the dependent variables.

\section{RESEARCH METHODOLOGY}

IFRS have important effect on the preparation of financial statements among businesses in Turkey, as well as on world accounting applications. Presenting and evaluating the said effects is important in terms of the application of current accounting and financial reporting standards. The national and international literature includes many empirical studies on IFRS. However, there are few studies that parallel The Analysis of Financial Reporting Process within the IFRS: An Empirical Research in the ISE. The importance of this research is related to a change in the financial statements items required of ISE companies, due to the transition to IFRS. Considering that this change has an effect on the analysis of financial statements, it is important to present the effect period of the IFRS on the quality of financial analysis.

There is not a universally accepted measure of financial reporting quality, however (Dechow et al., 2010). That is, a single proxy is unlikely to cover all facets of financial reporting quality. Givoly et al. (2010) and Chen et al. (2011) identified measures that capture the dimensions of financial reporting quality: as three measures of accruals persistence, cash flow predictability, and accruals quality.

IFRS aim to prepare financial situations, performance and cash flow of businesses in the most realistic way; to correctly display each operation affecting the financial statements; and to present the information in a suitable, reliable, comparable and understandable manner. The aim of this study is to determine the analysis and the effect of the financial reporting process within the scope of IFRS on companies operating in the ISE. According to the IASB's Conceptual Framework the objective of financial reporting is to provide information that is useful to investors and capital providers. The focus of the study is to collect and document the opinion of business managers, financial analysts and investors as financial information users.

A questionnaire form developed by the researcher was used during the research as a means of data collection. Also, behavioral attitudes and views of company managers, financial analysis and investors were made use of for determining whether the expressions in the scales were suitable for the research purpose and evaluating questionnaire form as a whole. The research utilizes regression analysis; ANOVA analysis and data were collected 
via a questionnaire distributed among all 366 companies registered on the ISE in August 2011. The questionnaire was sent to company managers, internal financial analysts and investors via e-mail, and 129 responses were received.

\section{EMPIRICAL RESULTS}

A5-point Likert-type scale was used in the questionnaire, and two basic evaluations were emphasized for more accurately presenting financial reporting analysis of IFRSharmonized businesses and influencing the quality of financial reporting. The evaluation involves regression analysis of the behaviors of business managers who participated in the questionnaire.

The Likert-type questions used the scale: (1) I absolutely disagree, (2) I disagree, (3) unsure, (4) I agree, (5) I certainly agree. Within this scope, the following table shows the results of regression analysis about more accurate financial analysis of businesses regarding the aforementioned questions in survey form.

To test my hypothesis H1, which predicts a positive relationship between IFRS and accurate information on financial reporting, I apply the following model:

$$
Y=\alpha+\beta 1 X+\beta 2 X+€
$$

Since (Y) IFRS presented new financial reporting understanding based on international amendments, the effect was measured of the independent variables presented in Table 1 on the dependent variable leading to more accurate financial reporting analysis.

Table 1: Regression Results: More Accurate Financial Analysis via IFRS

\begin{tabular}{|l|l|l|l|l|l|l|}
\hline Independent Variables & Average & $\begin{array}{l}\text { Standard } \\
\text { Deviation }\end{array}$ & N & Beta & $\begin{array}{l}\text { Standard } \\
\text { Error }\end{array}$ & Sig. \\
\hline $\begin{array}{l}\text { IFRS enable easier comparison of financial } 4,12 \\
\text { statements from previous periods }\end{array}$ &, 989 & 129 &,- 067 &, 358 &, 075 \\
\hline $\begin{array}{l}\text { Since IFRS ensure realistic financial } 4,01 \\
\text { reporting, more accurate information is } \\
\text { presented to capital investors with respect to } \\
\text { company activities, especially the asset or } \\
\text { capital structure analysis of the businesses }\end{array}$ &, 923 & 129 &, 358 &, 491 &, 000 \\
\hline $\begin{array}{l}\text { The use of common financial reporting } 4,29 \\
\text { language within IFRS facilitates the } \\
\text { monitoring of business development within } \\
\text { the financial analysis }\end{array}$ &, 654 & 129 &, 067 &, 367 &, 008 \\
\hline $\begin{array}{l}\text { IFRS promote more accurate identification of } 4,09 \\
\text { fund resources }\end{array}$ &, 984 & 129 &, 292 &, 298 &, 000 \\
\hline $\begin{array}{l}\text { The cash flow tables prepared according to } 4,04 \\
\text { IFRS result in more realistic results of } \\
\text { financial analysis }\end{array}$ &, 744 & 129 &, 209 &, 419 &, 000 \\
\hline
\end{tabular}




\begin{tabular}{|l|l|l|l|l|l|}
\hline \hline $\begin{array}{l}\text { Producing more accurate financial reporting } 4,57 \\
\text { information via IFRS financial statements, } \\
\text { and ensuring international comparability } \\
\text { between businesses, contributes to more } \\
\text { realistic financial analysis }\end{array}$ &, 513 & 129 &, 135 &, 418 &, 000 \\
\hline $\begin{array}{l}\text { Having a strong relationship between } 4,35 \\
\text { accounting profit and economic profit within }\end{array}$ &, 582 & 129 &, 165 &, 313 &, 000 \\
$\begin{array}{l}\text { IFRS contributes to more accurate analysis } \\
\text { of the business and profitability }\end{array}$ &, 759 & 129 &, 172 &, 310 &, 000 \\
\hline $\begin{array}{l}\text { The positive effect of financial reporting } 3,95 \\
\text { presented according to IFRS on the } \\
\text { investment, management and credit analysis } \\
\text { of businesses by providing more accurate } \\
\text { information about business activities to } \\
\text { financial reporting users. }\end{array}$ &, 633 & 129 &, 056 &, 583 &, 148 \\
\hline $\begin{array}{l}\text { IFRS contribute to the creation of realistic } 4,12 \\
\text { plans for the future through accurate analysis } \\
\text { of the financial performance of the business, } \\
\text { and to the determination of the aims by } \\
\text { setting pursuant targets. }\end{array}$ &, 574 & 129 &, 198 &, 418 &, 000 \\
\hline $\begin{array}{l}\text { The help of IFRS in accurate analysis of } 4,49 \\
\text { comparisons depending on financiat } \\
\text { performances of different businesses in the } \\
\text { same sector. }\end{array}$ & & & & & \\
\hline
\end{tabular}

The results shown in Table 1 indicate that, since IFRS allowed for international comparisons between businesses, they led to more accurate financial reporting analysis, which explained $95 \%$ of the variable causing more appropriate effect in financial measuring of business through independent variable in the table. Moreover, the regression analysis showed a significant positive relationship between independent variables and dependent variables. According to $\mathrm{p}$ values (Sig. F Change) in the table, the values are seen to be below 0.01 , except for the contribution of accurate analysis of financial performances of businesses to the creation of more realistic future plans through the facilitation of comparing previous financial reporting of businesses by IFRS. Therefore, an increase in the independent variables due to IFRS leads to an increase in the dependent variable of "ensuring high level reliability to the financial table users in financial measurement of the business". In addition, the regressive relationship in the variable facilitating the comparison of previous financial reporting of businesses by IFRS showed a significantly negative relationship.

The followings are variables emerging as a result of multiple regression analysis concerning the effect of IFRS in receiving more accurate financial analysis results of businesses and having more appropriate effect in measuring financial performances of 
businesses. The following variables also determined that IFRS gives more accurate results for financial analysis in financial measurements of ISE companies.

- $\quad$ IFRS help accurate analysis in comparisons that depend on the financial performance of other businesses in the same sector,

- IFRS increase the initiative of determining fund resources more accurately,

- Establishing a strong relationship between accounting profit and economic profit within IFRS-based financial reporting; contribution to more accurate assessment of profitability and analysis of the business,

- The use of common financial reporting language within IFRS facilitates monitoring of business development via analysis of the financial statements presented by businesses,

- $\quad$ Producing more accurate financial reporting information via the financial statements prepared according to IFRS, and ensuring international comparability between businesses, thereby contributing to more realistic financial analysis,

- $\quad$ Positively affecting the performance of investment, management and credit analysis of the businesses by presenting more accurate information to the users of financial statements, regarding business activities via financial reporting according to IFRS,

- More realistic financial analysis due to cash-flow statements prepared according to IFRS,

- IFRS contribute to the creation of realistic plans for the future by means of accurate analysis of the financial performance of the business, and to the determination of the aims by setting pursuant targets ,

- Since IFRS ensure realistic financial reporting, more accurate information about company activities is presented to capital investors, especially about assets or capital structure analysis of the businesses.

Therefore, regression analysis of dependent and independent variables shows that IFRS present more reliable data for users, and contribute to more accurate investment decisions by investors. It was also concluded that IFRS were effective in analyzing asset or capital structures.

According to Table 1, the opinion that IFRS offer more accurate information about the analysis of especially asset or capital structures of businesses through providing accurate financial reporting has the first rank with 0.358 points, which is the highest value among beta coefficients of the analysis regarding more accurate and effective financial analysis of businesses. The second-ranked finding was that IFRS increased the initiative of determining fund resources more accurately ( 0,292 Beta coefficient); third was: the beginning of the receiving of realistic results in the financial analysis due to cash-flow tables prepared according to IFRS (0.209). IFRS also facilitate more accurate analysis of other businesses in the same sector according to their financial performances. Therefore, the beta coefficients indicate that IFRS positively affect the analysis by providing more accurate and efficient financial analysis of the businesses. 
Table 2: Model Summary

\begin{tabular}{|c|c|c|c|c|c|}
\hline \multirow[b]{2}{*}{ Model } & \multicolumn{5}{|l|}{ Change Statistics } \\
\hline & R Square Change & F Change & df1 & df2 & Sig. F Change \\
\hline 1 &, 975 & 457,138 & 10 & 118 &, 000 \\
\hline
\end{tabular}

Table 3: ANOVA Values

\begin{tabular}{|l|l|l|l|l|l|l|}
\hline \multicolumn{2}{|l|}{ Model } & Sum of Squares & df & Mean Square & F & Sig. \\
\hline \multirow{2}{*}{1} & Regression & 11323,250 & 10 & 1132,325 & 457,138 &, 000 \\
\cline { 2 - 7 } & Residual & 292,285 & 118 & 2,477 & & \\
\cline { 2 - 7 } & Total & 11615,535 & 128 & & & \\
\hline
\end{tabular}

The study measured effect of the independent variables presented in Table 4 on the dependent variable that IFRS provide more accurate information to the financial statements users through positively affecting quality level of the financial statements analysis of businesses.

Table 4: Regression Analysis of the Effect of IFRS on the Quality of Financial Statements Analysis

\begin{tabular}{|l|l|l|l|l|l|l|}
\hline Independent Variables & Average & $\begin{array}{l}\text { Standard } \\
\text { Deviation }\end{array}$ & $\mathbf{N}$ & Beta & $\begin{array}{l}\text { Standard } \\
\text { Error }\end{array}$ & Sig. \\
\hline $\begin{array}{l}\text { IFRS positively affect accounting quality in terms of } 3,93 \\
\text { document and recording order }\end{array}$ & 1,062 & 129 &, 215 &, 215 &, 000 \\
\hline $\begin{array}{l}\text { IFRS positively affect the quality of analyzing } 4,02 \\
\text { inancial analysis }\end{array}$ &, 918 & 129 &, 185 &, 247 &, 000 \\
\hline $\begin{array}{l}\text { IFRS provide more reliable financial information for } \\
\text { making important business decisions }\end{array}$ &, 800 & 129 &, 321 &, 408 &, 000 \\
\hline $\begin{array}{l}\text { The adoption of IFRS positively affect the } 4,03 \\
\text { qualification level of accounting staff }\end{array}$ &, 770 & 129 &,- 022 &, 273 &, 319 \\
\hline \begin{tabular}{l} 
IFRS positively contribute to the reliability of 4,36 \\
\hline
\end{tabular} &, 556 & 129 &,- 032 &, 485 &, 260 \\
\hline
\end{tabular}




\begin{tabular}{|l|l|l|l|l|l|l|}
\hline \hline financial analysis & & & & & \\
\hline $\begin{array}{l}\text { IFRS present more accurate financial information } \\
\text { to users in determining the performance levels of } \\
\text { businesses }\end{array}$ &, 773 & 129 &, 150 &, 286 &, 000 \\
\hline $\begin{array}{l}\text { IFRS help in making appropriate decisions at every } \\
\text { stage of business activities }\end{array}$ &, 703 & 129 &, 146 &, 300 &, 000 \\
\hline $\begin{array}{l}\text { IFRS help in making comparisons on the same basis } 4,26 \\
\text { between different periods, and thus in making } \\
\text { appropriate decisions in subjects vitally important } \\
\text { for the business }\end{array}$ &, 679 & 129 &, 107 &, 354 &, 000 \\
\hline $\begin{array}{l}\text { IFRS increase the efficiency of the financial } 4,26 \\
\text { analysis by making audits of the business easier }\end{array}$ &, 549 & 129 &, 128 &, 302 &, 000 \\
\hline $\begin{array}{l}\text { IFRS increase the quality of both internal and } 4,19 \\
\text { external business analysis }\end{array}$ &, 527 & 129 &, 158 &, 546 &, 000 \\
\hline
\end{tabular}

According to Table 4, 96\% of the variation in the variable "IFRS positively affect the quality of analysis of financial statements" was explained by the independent variables of the table. Moreover, regression analysis showed a significant positive relationship between independent variables and dependent variables. The $p$ values (Sig. F Change) shown in the table are less than 0,01 , except for positively affecting the qualification levels of accounting staff though the application of IFRS, and IFRS positively contributing to the reliability of financial analysis results. Therefore, an increase occurred in the independent variables due to IFRS, leading to an increase in the dependent variable of providing users with high-quality financial analysis of the business. In addition, it was observed that the regression relationship was significantly negative for the variable "applying IFRS, positively affects the qualification level of accounting staff". This shows that the positive effect of IFRS on the qualification level of accounting staff is non-significant. Also, the regression relationship was negative in terms of IFRS making a positive contributing to the reliability level of the financial analysis results of the businesses. Therefore, it can be concluded the reliability of the financial analysis of ISE companies was unchanged between pre-IFRS and post-IFRS.

In conclusion, IFRS presented more accurate information to the users of financial statements in determining the performance levels of businesses by positively affecting the quality of the analysis of financial statements. Accordingly, it was concluded that among the variables that occurred as a result of IFRS were as follows;

- $\quad$ IFRS increase the quality of both internal and external analysis in the business,

- IFRS present more accurate information to the users of financial statements in determining the performance levels of businesses,

- IFRS increase the efficiency of the financial analysis, since they help make audits of the business easier,

- IFRS help in making appropriate decisions at every stage of business activities, 
- $\quad$ IFRS positively affect accounting quality in terms of document and recording order,

- $\quad$ IFRS positively affect the quality of financial statements analysis,

- IFRS provide a consistent basis for comparison of data from different periods, and thus aid in making appropriate decisions on subjects vitally important for the business,

- IFRS provide more reliable financial information for making important decisions in the businesses; IFRS increased the financial analysis quality level of ISE businesses and presented higher quality information to the users of financial data. Furthermore, IFRS provide more reliable information for making important decisions in the businesses.

Tablo 5: Model Summary

\begin{tabular}{|l|l|l|l|l|l|}
\hline \multirow{2}{*}{ Model } & \multicolumn{4}{l}{ Change Statistics } \\
\cline { 2 - 7 } & R Square Change & F Change & df1 & df2 & Sig. F Change \\
\hline 2 &, 982 & 628,357 & 10 & 118 &, 000 \\
\hline
\end{tabular}

Table 6: ANOVA Values

\begin{tabular}{|l|l|l|l|l|l|l|}
\hline \multicolumn{2}{|l|}{ Model } & Sum of Square & df & Mean Square & F & Sig. \\
\hline 2 & Regression & 11401,426 & 10 & 1140,143 & 628,357 &, 000 \\
\cline { 2 - 8 } & Residual & 214,109 & 118 & 1,814 & & \\
\cline { 2 - 7 } & Total & 11615,535 & 128 & & & \\
\hline
\end{tabular}

According to Table 4, participants expressed the strongest agreement that IFRS provide more reliable financial information for making important decisions $(0,321$, which is the highest value of beta coefficient regarding the effect of IFRS on the quality level of financial reporting analysis of businesses). The second-ranked response was that IFRS positively affect accounting quality in terms of document and recording order (beta coefficient 0,215$)$; third was that IFRS positively affect the quality of financial table analysis $(0,185)$. Moreover, the adoption of IFRS in the business increased the quality of both internal analysis and external analysis. The beta coefficient shows that IFRS have a positive effect on the quality of analysis of the business's financial statements.

The questionnaire responses indicated that, as IFRS facilitated international comparison between businesses, it led to more accurate financial analysis and more appropriate effect in measuring the business financially. It was also concluded that the variation in the variable "IFRS positively affected quality of financial table analysis" could be explained by independent variables. According to these results, hypotheses H1 and H2 are 
accepted in the case where the average values of the regression of the hypothesis, summary tables of the hypothesis models and ANOVA values are evaluated together.

\section{CONCLUSION}

Globalization of business required international companies to prepare financial reports in compliance with the accounting standards of each country in which they were active. The requirement of preparing multiple financial reports was costly and difficult for companies. Since businesses prepared different financial statements in different countries, investors had difficulty in comparing these data. A single set of accounting rules has the effect of reducing the operation costs associated with globalization. Thus, obligatory harmonization to IFRS began to accelerate in Turkey, as in many other countries. With the use of IFRS, companies prepared financial statements according to standards envisaged by international norms rather than according to generally accepted regional accounting standards.

According to Jones and Higgins (2006), there is some uncertainty among respondents about how IFRS would impact their internal operations and external financial reporting, although a number of respondents had a general sense of how their firm's profitability and financial position would be affected by the conversion to IFRS. Cheong et al. (2010), state that the change in accounting standards as a consequence of mandatory IFRS adoption may be imparting better quality information in financial statements. While IFRS adoption and domestic GAAP convergence with IFRS show that IFRS are a high quality set of accounting standards, the economic consequences of this change are still debated (Ahmed et al., 2013). Our paper contributes to this debate by reviewing a questionnaire survey of listed firms in the ISE of empirical studies dealing with financial reporting effects of IFRS, namely a high quality effect being the accuracy of financial analysts and financial reporting forecasts. The present study conducted a questionnaire survey of companies operating in the ISE, assessing: the financial analysis of managers, and the behavioral attitudes and evaluations of investors regarding the obligatory application of IFRS to financial analysis.

This study has reviewed the impact of IFRS adoption on the accounting quality of financial statements analysis and accurate financial analysis of listed companies in Turkey. Our result shows that the addition of new IFRS has caused an increase in the quality of financial reporting in Turkey. Accordingly, the results of evaluations regarding the contribution of IFRS to more accurate and more effective financial analysis businesses are as follows;

- $\quad$ IFRS ensure realistic financial reporting, presenting more accurate information about company activities to capital investors, especially about the asset or capital structure analysis of the businesses,

- $\quad$ IFRS increase the initiative of determining fund resources more accurately in the businesses,

- $\quad$ Due to the cash-flow statements prepared according to IFRS, more realistic results are obtained in the financial analysis, 
- Producing more accurate financial reporting information via financial statements prepared according to IFRS, and ensuring international comparability between businesses, thereby contributing to more realistic financial analysis,

- $\quad$ IFRS provide more accurate comparison of financial performances relative to other businesses in the same sector,

- $\quad$ IFRS contribute to more realistic assessment of profitability state, and analysis of the business. In contrast, it was found that IFRS did not make comparability of previous periods in the financial statements of the businesses easier.

Evaluations were also made about the effect of IFRS on the quality of the analysis of financial statements among companies operating in the ISE, of which the important points are as follows:

- IFRS provide more reliable financial information for making important decisions in the businesses,

- $\quad$ IFRS positively affect the quality of document and recording order during accounting,

- IFRS contribute to greater quality of both internal and external business analysis.

Finally, findings show that the adoption of IFRS on listed firms in Turkey significantly contributes to an improvement in financial analysis forecast accuracy. Our statistical analysis supports the majority of studies that make such an association. This result indicates that IFRS provide analysts with more useful information regarding firms' investments, managers, investors' and financing activities that have in turn contributed to the financial statements' users. Overall, our results show that IFRS benefit a firm's information environment through its effect on sophisticated users of financial analysts and investors. The findings in our study offer important and significant indicators for investors, financial information users, researchers and professional accountants. Our results suggest that financial statements prepared under IFRS assist financial analysts to more accurately forecast financial analysis and therefore allow investors to have more confidence in these forecasts.

This study is limited by the sample of firms on ISE in Turkey. Future research can examine measuring the impact of IFRS on market performance within financial reporting process.

\section{REFERENCES}

Ahmed, K., Chalmers, K. and Khlif, H. (2013), A Meta-analysis of IFRS Adoption Effects, The International Journal of Accounting, 48, 173-217.

Akgün, A.İ. (2013), The Impact of International Financial Reporting Standards on Financial Analysis: A Study On IMKB (Istanbul Stock Exchange), Journal of Doğuş University, Vol.: 14, Issue: 1, January 2013, 10-26. 
Aljifri, K. (2012), The Quality of IFRS Financial Reporting, Accounting and Marketing, Volume:1, Issue: 2, 2012, 1-2.

Armstrong, C.S., Barth, M.E., Jagolizer, A.D. and Riedl, E.J. (2010), Market reaction to the adoption of IFRS in Europe, The Accounting Review, 85 (1), 31-62.

Atwood, T.J. , Drake, M.S., Myers, J.N. \& Myers, L.A. (2011), Do Earnings Reported Under IFRS Tell Us More About Future Earnings and Cash Flows?, Journal of Accounting and Public Policy, 30 (2), March-April, 103-121.

Barth, M.E., Landsman, W.R. \& Lang, M.H. (2008), International Accounting Standards and Accounting Quality, Journal of Accounting Research, 46(3), 467-498.

Blanchette, Michel, Racicot, F-E. \& Girard, J-Y. (2011), The Effect of IFRS on Financial Ratios: Early Evidence in Canada, Canada: Certified General Accountants Association.

Bushman, R., Piotroski, J. (2006), Financial reporting incentives for conservative accounting: the influence of legal and political institutions, Journal of Accounting and Economics, 42, 107-148.

Byard, D., Li, Y., Yu, Y. (2011), The effect of mandatory IFRS adoption on financial analysts' information environment, Journal of Accounting Research, 49, 69-96.

Callao, S., Jarne, J.I. \& Laînez, J.A. (2007), Adoption of IFRS in Spain: Effect on the comparability and relevance of financial reporting, Journal of International Accounting, Auditing and Taxation, 16, 148-178.

CHEN, F., O-K. Hope, Q. Li, and X. Wang. (2011), Financial Reporting Quality and Investment Efficiency of Private Firms in Emerging Markets, The Accounting Review, 86 (4), 1255-1288.

Cheong, C. S., \& Al Masum, M. (2010), Financial analysts' forecast accuracy: Before and after the introduction of AIFRS, Australasian Accounting Business \& Finance Journal, $4(3), 65-81$.

Cheong, C.S., Kim, S. \& Zurbruegg, R. (2010), The impact of IFRS on financial analysts' forecast accuracy in the Asia-Pacific region: The case of Australia, Hong Kong and New Zealand, Pacific Accounting Review, 22(2), 124-146.

Choi, T.H.\& Pae, J. (2011), Business Ethics and Financial Reporting Quality: Evidence from Korea, Journal of Business Ethics, 103,403-427.

Christensen, HB, Lee, E and Walker, M. (2007), Cross-sectional variation in the economic consequences of international accounting harmonization: The case of mandatory IFRS adoption in the UK, The International Journal of Accounting, 42, 341-379.

Cortesi, A., Montani, E. \& Tettamanzi, P. (2009), IAS/IFRS Adoption by Italian Listed Companies: First Empirical Evidences, International Review of Business Research Papers, Vol. 5, No. 4, 388-398.

Covrig, V., DeFond, M., Hung, M. (2007), Home bias, foreign mutual fund holdings, and the voluntary adoption of International Accounting Standards, Journal of Accounting Research, 45, 41-70. 
Cuijpers, R, \& Buijink, W. (2005), Voluntary adoption of non-local GAAP in the European Union: A study of determinants and consequences, European Accounting Review, 14(3), 487-524.

Daske, H. (2006), Economic benefits of adopting IFRS or US-GAAP: Have the expected cost of equity capital really decreased?, Journal of Business Finance \& Accounting, 33(3\&4), 329-373.

Daske, H., Hail, L., Leuz, C., Verdi, R. (2008), Mandatory IFRS reporting around the world: early evidence on the economic consequences, Journal of Accounting Research, 46, 1085-1142.

Dechow, P., Ge, W. \& Schrand, C. (2010), Understanding earnings quality: A review of the proxies, their determinants and their consequences, Journal of Accounting and Economics, 50 (2-3), 344-401.

DeFond, M., X. Hu, M. Hung, and S. Li. (2011), The impact of mandatory IFRS adoption on foreign mutual fund ownership: The role of comparability, Journal of Accounting and Economics, 51 (3), 240-258.

Ding, Y.\&Su, X. (2008), Implementation of IFRS in a regulated market, Journal Account.Public Policy, 27, 474-479.

Ernstberger, J., Krotter, S. \& Stadler, C. (2008), Analysts' Forecast Accuracy in Germany: The Effect of Different Accounting Principles and Changes of Accounting Principles, Business Research Official Open Access Journal of VHB, Vol. 1(1), 26-53.

Gebhardt, G. \& Novotny-Farkas, Z. (2011), Mandatory IFRS Adoption and Accounting Quality of European Banks, Journal of Business Finance \& Accounting, 38(3) \& (4), 289-333.

Givoly, D., C. Hayn, and S.P. Katz (2010), Does public ownership of equity improve earnings quality?, The Accounting Review, 85 (1), 195-225.

Goodwin, J., Ahmed K. \& Heaney, R. (2008), The Effects of International Financial Reporting Standards on the Accounts and Accounting Quality of Australian Firms: A Retrospective Study, Journal of Contemporary Accounting \& Economics, 4(2), 89-119.

Hail, L., Leuz, C., Wysocki, P. (2010), Global accounting convergence and the potential adoption of IFRS by the U.S. (part I): conceptual underpinnings and economic analysis, Accounting Horizons, 24, 355-394.

Hamberg, M., Taylan Mavruk, T. and Sjögren, S. (2013), Investment allocation decisions, home bias and the mandatory IFRS adoption, Journal of International Money and Finance, 36,107-130.

Horton, J., Serafeim, G. \& Serafeim, I. (2013), Does Mandatory IFRS Adoption Improve the Information Environment?, Contemporary Accounting Research, 30(1), 388-423.

Hung, M., \& Subramanyam, K. R. (2007), Financial statement effects of adopting International Accounting Standards: The case of Germany, Review of Accounting Studies, 12(4), 623-657. 
Iatridis, G. (2010a), IFRS Adoption and Financial Statement Effect: The UK Case, International Research Journal of Finance and Economics, 38, 165-172.

Iatridis, G. (2010b), International Financial Reporting Standards and Financial Statement Information, International Review of Financial Analysis, 19, 193-204.

Jiao, T., Koning, M., Mertens G. \& Roosenboom P. (2012), Mandatory IFRS adoption and its impact on analysts' forecasts, International Review of Financial Analysis, 21, 56-63.

Jones, S. \& Higgins, A.D. (2006), Australia's switch to international financial reporting standards: a perspective from account preparers, Accounting and Finance, Vol. 46, 629-652.

Jones, S., \& Finley, A. (2011), Have IFRS made a difference to intra-country financial reporting diversity?, The British Accounting Review, 43(1), 22-38.

Landsman, W.R., Lang, M., Barth M.E. \& Williams C. (2012), Are IFRS-based and US GAAP-based accounting amounts comparable?, Journal of Accounting and Economics, 54, 68-93.

Landsman, W.R., Maydew, E.L. \& Thornock, J.R. (2012), The information content of annual earnings announcements and mandatory adoption of IFRS, Journal of Accounting and Economics, 53, $34-54$.

Lantto, A.M. \& Salstrom, P. (2009), Impact of International Financial Reporting Standard Adoption on Key Financial Ratios, Account and Finance, Vol. 49, 341-361.

Li, S. (2010), Does mandatory adoption of International Financial Reporting Standards in the European Union reduce the cost of equity capital?, The Accounting Review, 85, 607636.

Macias, M. \& Muino, F. (2011), Examining Dual Accounting Systems in Europe, The International Journal of Accounting, 46, 51-78.

Navarro-Garcîa J.C. \& Bastida F. (2010), An empirical insight on Spanish listed companies' perceptions of International Financial Reporting Standards, Journal of International Accounting, Auditing and Taxation, 19, 110-120.

Petreski, M. (2006), The Impact of International Accounting Standards on Firms, Financial Accounting and Reporting Section Meeting Paper, 2006, 1-12.

Quta, E.R. (2011), The Impact of International Financial Reporting Standards (IFRS) Adoption on the Accounting Quality of Listed Companies in Kenya, International Journal of Accounting and Financial Reporting, Vol. 1, No.1, 212-241.

Richardson, S. \& Tuna, İ. (2009), International Financial Statement Analysis (Chapter 17: Evaluating Financial Reporting Quality), New Jersey: John Wiley \& Sons, Inc.

Simga-Mugan C and Hosal-Akman N., (2005), Convergence to international financial reporting standards: The case of Turkey, International Journal of Accounting, Auditing and Performance Evaluation, Vol. 2, No. 1/2: 127-139.

Simga-Mugan C and Hosal-Akman N., (2012), Principles of Financial Accounting: Based on IFRS, London: MacGraw-Hill, Inc.

Stecher, J and Suijs, J. (2012), Hail, Procrustes! Harmonized accounting standards as a procrustean bed, Journal of Accounting and Public Policy, 31, 341-355. 
Stoian, F., Morariu, A., Mitea, N. \& Crecana, C. (2009), Financial Statement Understandability Based An Explanatory Notes, Annales Universitatis Apulensis Series Oeconomica, 11(1), 345-356.

Van Tendeloo, B. \& Vanstraelen, A. (2005), Earning Management under German GAAP versus IFRS, Europen Accounting Review, 4 (1), 155-180.

Young, D., Guenther, D.A. (2002), Financial reporting environments and international capital mobility, Journal of Accounting Research, 41, 553-579. 
